\title{
Green Corrosion Inhibitor in Central Air-Conditioning Cooling Water
}

\author{
M.D. Li, B. Yang, J.M. Zhao, Y.T. Chen, S.X. Gu \\ Guangzhou Special Pressure Equipment Inspection and \\ Research Institute \\ Guangdong, China
}

\author{
C.L. Dai \\ Changsha University of Science \& Technology \\ Changsha, China
}

\begin{abstract}
The occurrence of metal corrosion can greatly reduce the air-conditioning efficiency, and even affect the safe and stable operation of equipment in central air-conditioning cooling water circulation system. Adding corrosion inhibitor to cooling water system is currently the most commonly and effective method. Electrochemical impedance method is used to evaluate the corrosion performance of single sodium tungstate, sodium molybdate, and sodium gluconate, while polarization curve method is used to evaluate the corrosion performance of two compound agent. Results show that corrosion performance of sodium tungstate, sodium molybdate, and sodium gluconate is ranged as follows: sodium tungstate $>$ sodium gluconate $>$ sodium molybdate. There has synergistic effect between sodium tungstate and sodium gluconate, as well as between sodium tungstate and sodium molybdate, and mixed use can improve corrosion effect. The optimized prescription is that, the sodium tungstate is 65 $\mathrm{mg} / \mathrm{L}$, sodium molybdate is $35 \mathrm{mg} / \mathrm{L}$, by this way, the corrosion rate can reach $98.31 \%$.
\end{abstract}

Keywords-sodium tungstate; sodium molybdat; sodium gluconate; polarization curve method; electrochemical impedance method; inhibition rate

\section{INTRODUCTION}

In recent years, the centralized central air-conditioning system has been widely used in civil construction, which is generally divided into three parts, namely the circulating cooling water system, chilled water system, and heating water systems. The three water systems have different features, but the same existing problems are scaling, corrosion and biological slime. If not treated properly, it will cause blockage, corrosion leakage, heat transfer efficiency reduction, and even affects the normal work of the whole air-conditioning system [1].

At present, adding chemicals into the circulating cooling water (scale inhibitor, corrosion inhibitor, bactericide) is the most popular method to control the scaling, corrosion and biological slime [2]. The study of scale inhibitor and bactericide has been relatively mature, environmental protection and high-efficiency scale inhibitors, such as polyaspartic acid and polyepoxysuccinic acid have been widely used[3]. Inhibition effect of phosphorus corrosion inhibitors is good, but their biodegradability is poor, which will cause eutrophication, and seriously pollute water bodies if discharged into the water environment. Therefore, developing a new type of environmentally friendly and phosphorus free corrosion inhibitor becomes today's important problem to be solved in environmental protection and water treatment field.

\section{MATERIALS AND METHODS}

\section{A. Instruments and Reagents}

Instruments: Electrochemical workstation(CHI660C); Analytical balance (AUY120).

Reagents: Sodium tungstate $\left(\mathrm{Na}_{2} \mathrm{WO}_{4}\right)$, chemically pure; Sodium molybdate $\left(\mathrm{Na}_{2} \mathrm{MoO}_{4}\right)$, chemically pure; Sodium gluconate $\left(\mathrm{C}_{6} \mathrm{H}_{11} \mathrm{NaO}_{7}\right)$, analytically pure.

\section{B. Experimental Method}

1) Polarization curve method: Three-electrode system is adopted, auxiliary electrodes are platinum electrode (213), reference electrodes are saturated calomel electrode (232). Working electrodes are A3 carbon steel, specification is 11 $\mathrm{mm} \times 9 \mathrm{~mm} \times 5 \mathrm{~mm}$, the surface of the sample retains $1 \mathrm{~cm}^{2}$, and the rest are embedded with epoxy resin. Working electrodes are burnished step by step by 320 mesh, 500 mesh, 1000 mesh sandpaper and 1 \#, 4 \# metallographic sandpaper until the metal body is bright and uniform, and then washed by deionized water, blotted up by filter paper, wiped and degreased by acetone[4]. Electrochemical workstation (CHI660C) and the corresponding data processing software are used to measure and analyze the potentiostatic polarization curves of A3 carbon steel in tap water and tap water adding corrosion inhibitor. Scan rate is $5 \mathrm{mV} / \mathrm{s}$, scanning potential range is chosen according to different situations. Tafel linear extrapolation method is used to get the corrosion current density, so as to calculate the inhibition rate.

2) AC impedance method: Electrochemical workstation (CHI660C) is used, three electrodes system and research electrode processing are just as polarization curve method above. The test frequency range is $100 \mathrm{KHz} \sim 10 \mathrm{MHz}$ or 10 $\mathrm{KHz} \sim 1 \mathrm{MHz}$, scanning mode is from high frequency to low frequency. AC signal is applied in the open circuit potential, and voltage amplitude is $\pm 5 \mathrm{mV}$ [5].

\section{RESULTS AND DISCUSSION}

\section{A. Inhibition Performance Evaluation of Single Agent}

1) Inhibition performance evaluation of sodium tungstate: AC impedance technology is used to get the impedance spectra of carbon steel electrode in the condition of tap 
water(blank experience), $40 \mathrm{mg} / \mathrm{L}, 60 \mathrm{mg} / \mathrm{L}, 80 \mathrm{mg} / \mathrm{L}, 100$ $\mathrm{mg} / \mathrm{L}, 120 \mathrm{mg} / \mathrm{L}$ sodium tungstate, and the impedance spectra are shown in Figure 1.

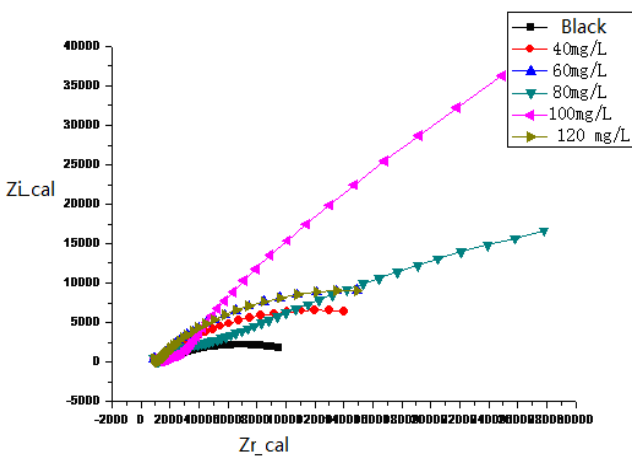

FIGURE I. INHIBITION RATE OF SODIUM TUNGSTATE.

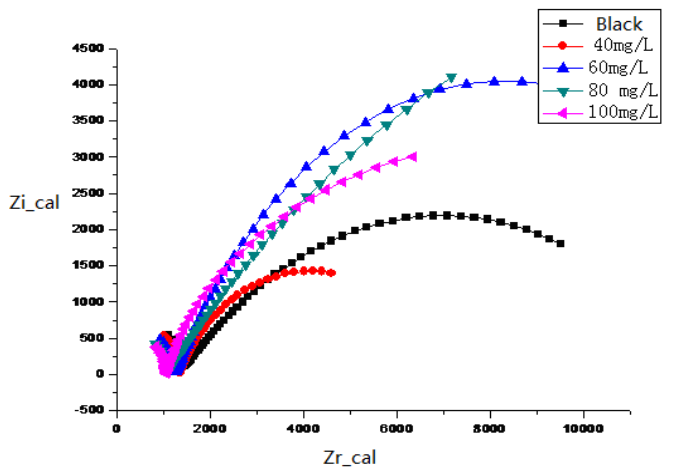

FIGURE II. INHIBITION RATE OF SODIUM MOLYBDATE.

2) Inhibition performance evaluation of sodium molybdate: AC impedance technology is used to get the impedance spectra of carbon steel electrode in the condition of tap water(blank experience), $40 \mathrm{mg} / \mathrm{L}, 60 \mathrm{mg} / \mathrm{L}, 80 \mathrm{mg} / \mathrm{L}, 100$ $\mathrm{mg} / \mathrm{L}$ sodium molybdate, and the impedance spectra are shown in Figure 2.

As shown in Figure1 and Figure2, the impedance value of adding sodium molybdate and sodium tungstate was greater than that in blank test, that is, sodium molybdate and sodium tungstate had corrosion effect on carbon steel. With the increasing of the dosage, impedance values increased. the best dosage of single sodium molybdate was $80 \mathrm{mg} / \mathrm{L}$, while the sodium tungstate was $100 \mathrm{mg} / \mathrm{L}$.

3) Inhibition performance evaluation of sodium gluconate: AC impedance technology is used to get the impedance spectra of carbon steel electrode in the condition of tap water(blank experience), $40 \mathrm{mg} / \mathrm{L}, 60 \mathrm{mg} / \mathrm{L}, 80 \mathrm{mg} / \mathrm{L}, 100$ $\mathrm{mg} / \mathrm{L}, 120 \mathrm{mg} / \mathrm{L}$ sodium gluconate, and the impedance spectra are shown in Figure 3.

As shown in Figure 3, the impedance value of adding sodium gluconate was greater than that in blank test, that is, sodium gluconate had corrosion effect on carbon steel. With the increasing of sodium gluconate dosage, impedance values increased, When the dosage of sodium gluconate reached 80 $\mathrm{mg} / \mathrm{L}$, impedance values fell instead, that means the best dosage of single sodium gluconate was $80 \mathrm{mg} / \mathrm{L}$.

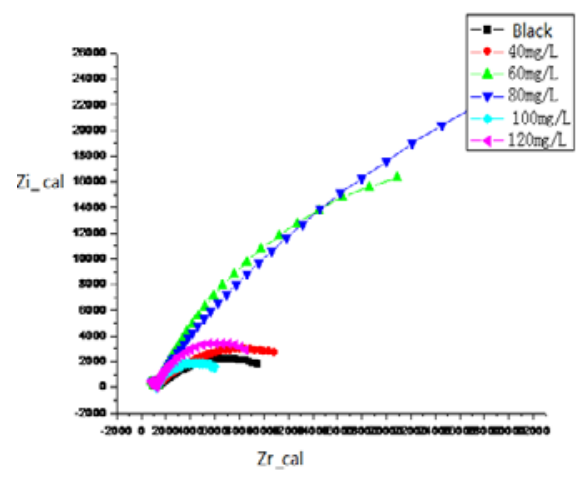

FIGURE III. INHIBITION RATE OF SODIUM GLUCONATE.

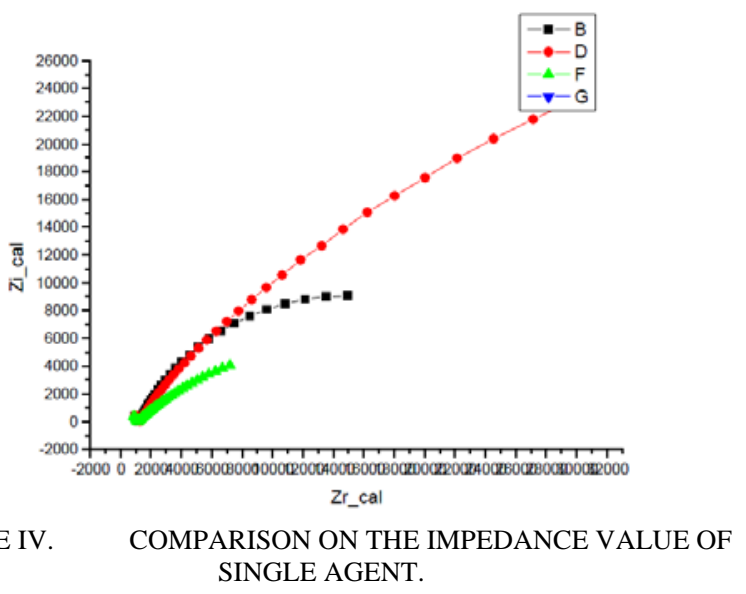

4) Comparison on the corrosion effect of single agent: AC impedance technology is used to get the impedance spectra of carbon steel electrode in the condition of tap water(blank experience), $100 \mathrm{mg} / \mathrm{L}$ sodium tungstate, $80 \mathrm{mg} / \mathrm{L}$ sodium molybdate, $80 \mathrm{mg} / \mathrm{L}$ sodium gluconate, and the impedance spectra are shown in Figure 4. Among which G is for blank, F is for sodium molybdate, D is for sodium gluconate, and B is for sodium tungstate.

As shown in Figure 4, under the best dosage of single agent, the impedance value of sodium tungstate was maximum, while the impedance value of sodium molybdate was minimum, that is, in terms of corrosion effect, the three kinds of agent were arranged as follows: sodium tungstate > sodium gluconate > sodium molybdate.

\section{B. Inhibition Performance Evaluation of Compound Agent}

According to the corrosion performance evaluation results of single agent, sodium tungstate had the best corrosion effect. Compounding sodium tungstate with sodium molybdate and sodium gluconate, respectively, the total concentration of compound agent is fixed to $100 \mathrm{mg} / \mathrm{L}$, polarization curve method is used to investigate the corrosion effect of compound agent on carbon steel.

1) Compound of sodium tungstate and sodium molybdate: The total concentration of compound agent is fixed to $100 \mathrm{mg} / \mathrm{L}$, the mass fraction of sodium tungstate is set as $65 \%$, 
$70 \%, 75 \%, 80 \%, 90 \%$, and polarization curve method is used. The experimental results are shown in Figure 5.

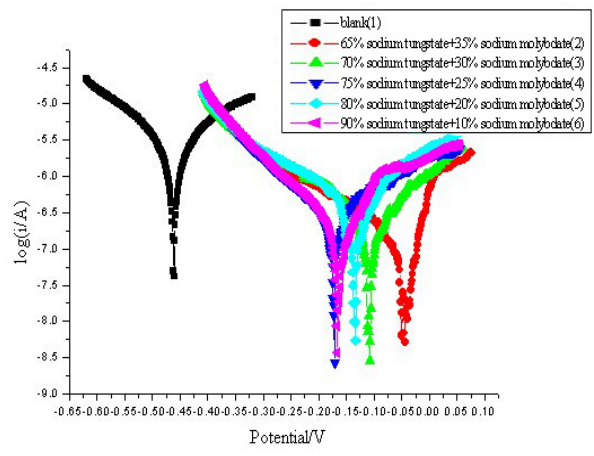

FIGURE V. POLARIZATION CURVES OF COMPOUND SODIUM TUNGSTATE AND SODIUM MOLYBDATE.

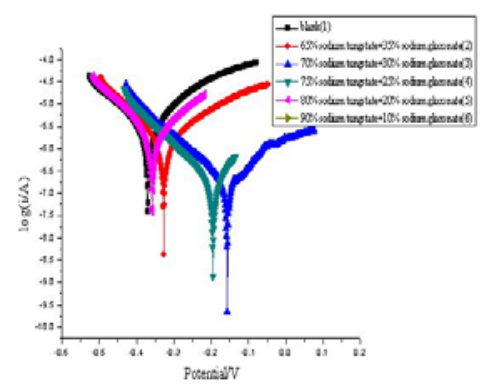

FIGURE VI.

POLARIZATION CURVES OF COMPOUND SODIUM TUNGSTATE AND SODIUM GLUCONATE.

Corrosion current and inhibition rate of sodium tungstate and sodium molybdate under different proportion were shown in table 1

TABLE I. ASSOCIATIVE RESULTS OF SODIUM TUNGSTATE AND SODIUM MOLYBDATE.

\begin{tabular}{lccc}
$\mathrm{Na}_{2} \mathrm{WO}_{4}$ & $\mathrm{Na}_{2} \mathrm{MoO}_{4}$ Corrosion current & $10^{-6}\left(\mathrm{~A} / \mathrm{m}^{2}\right)$ & Inhibition rate(\%) \\
\hline 0 & 0 & 3.54 & $/$ \\
65 & 35 & 0.17 & 95.31 \\
70 & 30 & 0.26 & 92.65 \\
75 & 25 & 0.42 & 88.10 \\
80 & 20 & 0.56 & 84.10 \\
90 & 10 & 0.26 & 93.53
\end{tabular}

From table 1 we can see that the corrosion rate can reach $98.31 \%$, which was highest, when the dosage of sodium tungstate was $65 \mathrm{mg} / \mathrm{L}$, and sodium molybdate was $35 \mathrm{mg} / \mathrm{L}$. As shown in Figure5, the corrosion potential of carbon steel moved in the positive direction, and the corrosion current reduced at the same time, that is, there had synergy between sodium molybdate and sodium tungstate.

2) Compound of sodium tungstate and sodium gluconate: The total concentration of compound agent is fixed to $100 \mathrm{mg} / \mathrm{L}$, the mass fraction of sodium tungstate is set as $60 \%$, $65 \%, 70 \%, 80 \%, 90 \%$, and polarization curve method is used. The experimental results are shown in Figure 6.
Corrosion current and inhibition rate of sodium tungstate and sodium gluconate under different proportion were shown in table 2

TABLE 2: ASSOCIATIVE RESULTS OF SODIUM TUNGSTATE AND SODIUM GLUCONATE.

\begin{tabular}{|c|c|c|c|}
\hline $\mathrm{Na}_{2} \mathrm{WO}_{4}$ & $\mathrm{C}_{6} \mathrm{H}_{11} \mathrm{NaO}_{7}$ & Corrosion current $10^{-6}\left(\mathrm{~A} / \mathrm{m}^{2}\right)$ & Inhibition rate (\%) \\
\hline 0 & 0 & 3.54 & / \\
\hline 60 & 40 & 2.02 & 42.97 \\
\hline 65 & 35 & 1.41 & 60.09 \\
\hline 70 & 30 & 0.42 & 88.10 \\
\hline 80 & 20 & 0.21 & 94.08 \\
\hline 90 & 10 & 1.02 & 71.82 \\
\hline
\end{tabular}

From table 2 we can see that the corrosion rate could reach $94.08 \%$, which was the highest, when the dosage of sodium tungstate was $80 \mathrm{mg} / \mathrm{L}$, and sodium gluconate was $20 \mathrm{mg} / \mathrm{L}$. As shown in Figure 6, the corrosion potential of carbon steel moved in the positive direction as the mass fraction of sodium tungstate increased, while the corrosion potential of carbon steel moved in the negative direction when the mass fraction of sodium tungstate reached $70 \%$, and the corrosion current increased at the same time, that is, there had synergy between sodium gluconate and sodium tungstate.

\section{CONCLUSIONS}

(1)AC impedance technology is used to evaluate the corrosion inhibition of single sodium tungstate, sodium molybdate, and sodium gluconate. Results show that the best dosage of single sodium tungstate is $100 \mathrm{mg} / \mathrm{L}$, while the best dosage of single sodium molybdate and sodium gluconate is $80 \mathrm{mg} / \mathrm{L}$, the corrosion effect of three kinds of corrosion inhibitors for carbon steel are arranged as follows: sodium tungstate $>$ sodium gluconate $>$ sodium molybdate.

(2) There has synergy between sodium molybdate and sodium tungstate, and the corrosion rate can reach $98.31 \%$, which is highest, when the dosage of sodium tungstate is 65 $\mathrm{mg} / \mathrm{L}$, and sodium molybdate is $35 \mathrm{mg} / \mathrm{L}$.

(3) There has synergy between sodium gluconate and sodium tungstate, and the corrosion rate can reach $94.08 \%$, which is highest, when the dosage of sodium tungstate is 80 $\mathrm{mg} / \mathrm{L}$, and sodium gluconate is $20 \mathrm{mg} / \mathrm{L}$.

\section{REFERENCES}

[1] H.G. Luo, R.G. Shi, Chemical treatment of central air-conditioning water system. Contamination Control \& Air-Conditioning Technology, 02, pp. 69-70, 2011.

[2] Series 13: The central air-conditioning water treatment technology. Guangdong Communication Technology, 08, p. 42-47, 2009.

[3] D.F. Zeng, J.G. Xiao, Development and application of environmentally friendly and phosphorus free scale and corrosion inhibitor. Cleaning World, 03, pp. 22-27, 2010.

[4] Abd-El-Khalek, D.E., Abd-El-Nabey, B.A., Evaluation of sodium hexametaphosphate as scale and corrosion inhibitor in cooling water using electrochemical techniques. Desalination, 311, pp. 227-233, 2013.

[5] R. Touir, N. Dkhireche, M. Ebn Touhami, Corrosion and scale processes and their inhibition in simulated cooling water systems by monosaccharides derivatives, Part I: EIS study. Desalination, 249, pp. 922-928, 2009. 